\title{
SISTEM PENJUALAN PERLENGKAPAN CACI BERBASIS WEB PADA TOKO RATU BORONG KABUPATEN MANGGARAI FLORES NTT
}

\author{
Ivonius Hendra Pedo ${ }^{1}$, Tjatursari Widiartin ${ }^{2}$ \\ 1,2 Program Studi Informatika, Fakultas Teknik, Universitas Wijaya Kusuma Surabaya \\ Hendrapedo0395@gmail.com, widiartin@gmail.com
}

\begin{abstract}
Abstrak
Tari Caci adalah kesenian tradisional setejenis tarian perang yang khas dari masyarakat manggarai di pulau Flores.Nusa Tenggara Timur. Tarian ini merupakan tarian yang di mainkan oleh dua penari laki-laki yang menari dan saling bertarung dengan menggunakan cambuk dan prisai sebagai senjatanya, Masalah yang terjadi pada toko Ratu kurangnya pemasaran mengakibatkan kurangnya pemasukan. Penelitian ini bertujuan untuk memecakan permasalahan yang terjadi di toko ratu dan munculkan gagasan untuk membuat sebuah aplikasi Berbasis Web. Sistem di buat berbasis web menggunakan pemrograman PHP dan database MYSQL.Metodologi yang di gunakan dalam pembuatan aplikasi ini adalah metode SDLC (System Development Life Cicle). Adapun hasil yaitu sistem dapat menampilkan produk yang di jual, kategori produk, pemesanan, pengiriman barang. Kebutuhan sistem aplikasi ini di antaranya para pelanggan dapat mencari segala perlengkapan caci pada toko Ratu yang ada pada aplikasi perlengkapan caci berbasis Web.
\end{abstract}

Kata kunci : Tari Caci, Sistem penjualan, Web.

\begin{abstract}
Caci dance is a traditional art, a type of war dance that is typical of the Manggarai community on the island of Flores, East Nusa Tenggara. This dance is a dance that is played by two male dancers who dance and fight each other using a whip and shield as their weapons. The problem that occurs at Ratu's shop is lack of marketing resulting in a lack of income.This study aims to solve the problems that occur in the queen shop and come up with an idea to create a Web-based application. The system is made web-based using PHP programming and MYSQL database.The methodology used in making this application is the SDLC (System Development Life Cicle) method. The results are that the system can display products being sold, product categories, ordering, shipping goods. The need for this application system includes customers being able to search for all drawer equipment at Ratu's shop that is on a Web-based drawer equipment application.
\end{abstract}

Keywords: Caci Dance, Sales system, Web.

\section{PENDAHULUAN}

Caci atau tari Caci atau adalah tari perang sekaligus permainan rakyat antara sepasang penari laki-laki yang bertarung dengan cambuk dan prisai di Manggarai, Nusa Tenggara Timur, Indonesia. Penari yang bersenjatakan cambuk (pecut) bertindak sebagai penyerang dan seorang lainnya bertahan dengan menggunakan perisai (tameng). Tari ini dimainkan saat syukuran musim panen (hang woja) dan ritual tahunan baru (penti), upacara pembukaan lahan atau upacara adat besar lainnya, serta dipentaskan untuk menyambut tamu penting dalam setiap kegiatan acara pesta pasti selalu dibutuhkan tarian Caci dan selalu dicari property seperti larik, nggiling, sapu, towe, slendang, celana putih, nggorong, panggal dan sebaigainya.Untuk penjualan properti di daerah Manggarai memang banyak karena tarian Caci menjadi salah satu tarian khas daerah Manggarai sehingga mudah untuk mendapatkannya di setiap sudut kota. Salah satu penyedia kebutuhan tersebut adalah Toko Ratu yang didirkan tahun 2015 oleh Oktavianus Poyong karena menangkap peluang menguntungkan.
Dalam dua tahun belakangan penjualan kurang meningkat, mungkin masyarakat luas belum terlalu familiar dengan yang namanya Caci, mungkin masyarakat daerah Manggarai saja yang tau apa itu Caci, karena kurang luasnya promosi sehingga masyarakat umum kurang paham tentang Caci.

Memang dalam hal ini property yang dijual masih secara manual sehingga masyarakat luas sulit untuk menemukannya, karena penjualan hanya ada di daerah Manggarai saja. Adapun salah satu cara yang dapat dilakukan untuk meningatkan penjualan dalam konsep bauran pemasaran yaitu dengan promosi yang diantaranya melalui media online. Dengan adanya promosi secara online akan memperluas infromasi kepada masyarakat yang diharapkan akan semakin banyak orang yang mengenal Caci sehingga tertarik dan mudah untuk mengaksesnya yang pada akhirnya akan meningkatkan transaksi atas produk Caci. Berdasarkan latar belakang masalah di atas maka dibuatlah aplikasi untuk memudahkan para pembeli untuk membeli property Caci.

\subsection{Pengertian Sistem}


Sistem adalah rangkaian dari dua atau lebih komponen-komponen yang terintegrasi melalui proses yang yang saling berhubungan dan berinteraksi untuk mencapai suatu tujuan.Sebagian besar sistem terdiridari subsistem yang lebih kecil yang mendukung. sistem yang lebih besar Sistem merupakan serangkaian bagian yang saling tergantung dan bekerja sama untuk mencapai tujuan tertentu.

Ada beberapa karakterisktik sistem, yaitu sebagai berikut :

1. Setiap sistem terdiri unsur-unsur yang membentuk subsistem

2. Unsur-unsur tersebut merupakan bagian terpadu sistem yang bersangkutan

3. Unsur sistem tersebut bekerja sama untuk mencapai tujuan tertentu

4. Suatu Sistem merupakan bagian dari sistem lain yang lebih besar.

\subsection{Pengertian Informasi}

Informasi merupakan data yang telah diolah dan diatur ulang menjadi suatu bentuk yang lebih berarti dan ditunjukan untuk seseorang. Informasi dibentuk dari kombinasi data yang diharapakan memiliki arti bagi penerimanya.

Informasi yang berguna memiliki karatekristik sebgai berikut :
1. Akurat
2. Tepat waktu
3. Lengkap
4. Ringkas

\subsection{Defenisi Internet}

Internet merupakan jaringan komputer yang dibentuk oleh Departemen Pertahanan Amerika Serikat pada tahun 1969, melalui proyek ARPA yang disebut ARPANET(Advanced Research Project Agency Network), di mana mereka mendemonstrasikan bagaimana dengan hardware dan software komputer yang berbasis UNIX, kita bisa melakukan komunikasi dalam jarak yang tidak terhingga melalui saluran telepon.Proyek ARPANET merancang bentuk jaringan, kehandalan, seberapa besar informasi dapat dipindahkan, dan akhirnya semua standar yang mereka tentukan menjadi cikal bakal pembangunan protokol baru yang sekarang dikenal sebagai TCP/IP (Transmission Control Protocol/Internet Protocol).

Tujuan awal dibangunnya proyek itu adalah untuk keperluan militer. Pada saat itu Departemen Pertahanan Amerika Serikat membuat sistem jaringan komputer yang tersebar dengan menghubungkan komputer di daerah-daerah vital untuk mengatasi masalah bila terjadi serangan nuklir dan untuk menghindari terjadinya informasi terpusat, yang apabila terjadi perang dapat mudah dihancurkan.

Pada mulanya ARPANET hanya menghubungkan 4 situs saja yaitu Stanford Research Institute, University of California, Santa Barbara, University of Utah, di mana mereka membentuk satu jaringan terpadu pada tahun 1969, dan secara umum ARPANET diperkenalkan pada bulan Oktober 1972. Tidak lama kemudian proyek ini berkembang pesat di seluruh daerah, dan semua universitas di negara tersebut ingin bergabung, sehingga membuat ARPANET kesulitan untuk mengaturnya.Oleh sebab itu ARPANET dipecah manjadi dua, yaitu "MILNET" untuk keperluan militer dan "ARPANET" baru yang lebih kecil untuk keperluan non-militer seperti, universitas-universitas. Gabungan kedua jaringan akhirnya dikenal dengan nama DARPA Internet, yang kemudian disederhanakan menjadi Internet.

\subsection{Pengertian Website}

Website atau situs dapat diartikan sebagai kumpulan halaman-halaman yang digunakan untuk menampilkan informasi teks, gambar diam atau gerak, animasi, suara, dan atau gabungan dari semuanya baik yang bersifat statis maupun dinamis. Hubungan antara satu halaman web dengan halaman web yang lainnya disebut hyperlink, sedangkan teks yang dijadikan media penghubung disebut hypertext.

\subsection{Pengertian SDLC}

System Development Life Cycle (SDLC) adalah suatu pendekatan yang memiliki tahap atau bertahap untuk melakukan analisa dan membangun suatu rancangan sistem dengan menggunakan siklus yang lebih spesifik terhadap kegiatan pengguna (Kendall \& Kendall, 2006). Dalam Metode SDLC terdapat tujuh tahapan pengembangan seperti yang ditunjukkan pada gambar berikut :

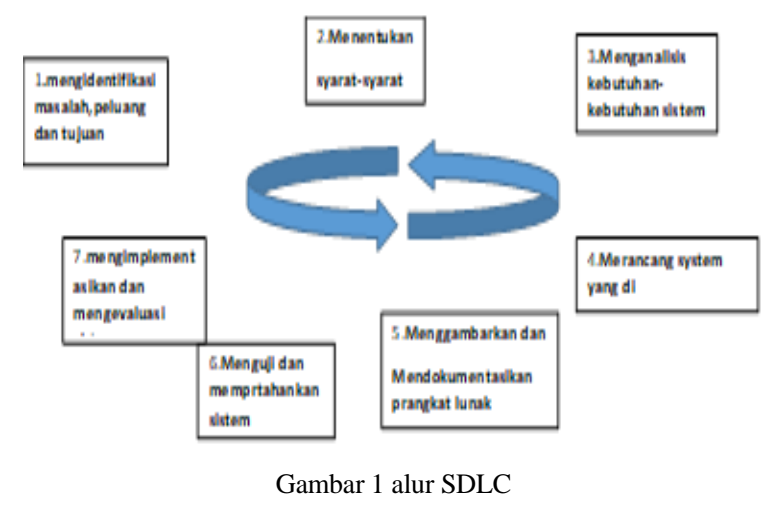

\subsection{Pengertian DFD}

Data Flow Diagram (DFD) adalah suatu diagram yang menggunakan notasi-notasi untuk menggambarkan arus dari data sistem, yang penggunaannya sangat membantu untuk memahami 
sistem secara logika, tersruktur dan jelas (Pahlevy. 2010.). DFD merupakan alat bantu dalam menggambarkan atau menjelaskan sistem yang sedang berjalan logis. Dalam sumber lain dikatakan bahwa DFD ini merupakan salah satu alat pembuatan model yang sering digunakan, khususnya bila fungsi- fungsi sistem merupakan bagian yang lebih penting dan kompleks dari pada data yang dimanipulasi oleh sistem. Dengan kata lain, DFD adalah alat pembuatan model yang memberikan penekanan hanya pada fungsi sistem. DFD ini merupakan alat perancangan sistem yang berorientasi pada alur data dengan konsep dekomposisi dapat digunakan untuk penggambaran analisa maupun rancangan sistem yang mudah dikomunikasikan oleh profesional sistem kepada pemakai maupun pembuat program.

\subsection{Pengertian Flowchart}

Flowchart merupakan gambar atau bagan yang memperlihatkan urutan dan hubungan antar proses beserta instruksinya. Gambaran ini dinyatakn dengan simbol. Dengan demikian setiap simbol menggambarkan proses tertentu. sedangkan hubungan antar proses digambarkan dengan garis penghubung. Flowchart ini merupakan langkah awal pembuatan program.Dengan adanya flowchart urutan proses kegiatan menjadi lebih jelas. Jika ada penambahan proses maka dapat dilakukan lebih mudah. setelah Flowchart selesai disusun selanjutnya pemrograman menerjemahkan nya ke bentuk program dengan bahasa pemrograman.

\section{METODE}

Metode penelitian berisi langkah langkah yang di gunakan dalam penelitian ini agar trustrur dengan bak. Adapun langkah - langkah yang dilakukan untuk mencapai tujuan penelitian ini.

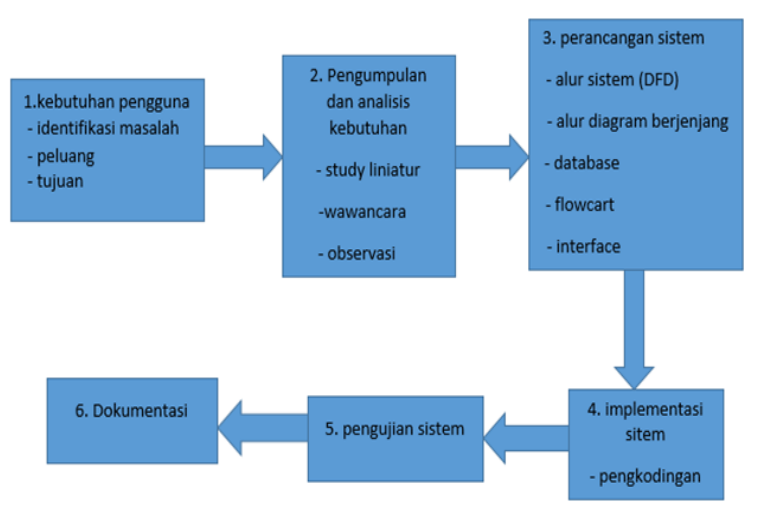

Gambar 2 alur penelitian

Adapun penjelasan mengenai langkah - langkah metode penelitian yang terterah pada gambar di atas

\subsection{Kebutuhan Pengguna}

Bagian tahapan ini dimana dilakukan sebuah analisa untuk menentukan kebutuhan penguna dari pokok permasalahan yang dihadapi toko Ratu menjadi objek dalam penelitian yang dilakukan untuk menentukan peluang dengan pembuatan sistem penjualan perlengkapan Caci. Dalam pembuatan sistem ini adapun tujuan dalam pembutan sistem agar bisa memberikan informasi penjualan perlengkapan Caci yang dibutuhkan oleh pengguna pada sistem penjualan perlengkapan Caci.

\subsection{Pengumpulan data dan analisa kebutuhan}

Pada tahapan kebutuhan sistem ini dimana dilakukan sebuah analisa kebutuhan sistem yang diperlukan yaitu data serta alur dari data tersebut untuk mengahsilkan informasi yang dibutuhkan oleh penguna dengan pengembangan sistem penjualan perlengkapan Caci berbasis web di toko Ratu borong.

Berikut adalah beberapa teknik penelitian dalam pengumpulan data dan informasi sebagai berikut :

1. Studi Literatur bagian penelitian yang dilakukan melalui referensi (Buku) untuk mengumpulkan informasi dimana menjadi tujuan pengembangan sistem informasi penjualan perlengkapan Caci berbasis web.

2. Wawancara interaksi lansung di lapangan dimana ada proses tanya jawab lansung dengan pemilik toko untuk mengumpukan data yang deperlukan dalam pembuatan sistem informasi penjualan perlengkapan Caci berbasis web.

3. Observasi Lapangan adalah salah analisa yang dilakukan di lapangan dimana pemilik toko menjadi objek observasi informasi yang dibutuhkan untuk membuat sistem informasi penjualan perlengkapan Caci berbasis web.

\subsection{Perancangan Sistem}

Setelah melakukan analisa kebutuhan sitem, maka tahap selanjutnya adalah pengembangan sistem.

\subsubsection{Data Flow Diagram (DFD)}

Pada tahap analisa data flow diagram akan di lakukan analisa sistem yang meliputi beberapa proses pada data flow diadram sebagai berikut:

\subsubsection{DFD Level kontex sistem Penjualan Perlengkapan Caci}

Pada proses dfd level kontex di mana pada proses ini meliputi alur kerja sistem secara umum di mana pada tahap analisa dfd level kontex akan menganalisa data dan alur sistem untuk menghasilkan informasi sesuai dengan kebutuhan pelanggan.

Berikut merupakan data dan alur pada kebutuhan sistem yang di analisa secara menyeluruh, dari proses login admin, terus login pelanggan, sistem 
menampilkan informasi barang, pelanggan memesan produk, sistem menampilkan data pesanan, pelanggan melakukan pembayaran, sistem validasi pembayaran, sampai proses pengiriman barang an pembuatan laporan ke pemilik toko. Berikut adalah alur pada sistem dengan data flow diagram level kontex:

\subsubsection{DFD level 1 sistem penjualan perlengkapan} Caci caci

Pada proses admin melakukan login, admin input data diri memasukan email dan password. Berikutnya pelanggan untuk transaksi pembelian, di sini langka pertama yang di lakukan pembeli input akun email dan password, setelah itu data akun pelanggan akan di simpan di data akun pelanggan, setelah itu dari sistem akan mengeluarkan konfirmasi email dan password, setelah memasukan email pelanggan bisa memesan perlengkapan caci dan sistem akan informasi total produk yang di beli, data pesanan akan tersimpan di data pesanan dari data pesanan akan memasukan validasi data pesanan ke sistem, setelah melakukan pesanan berikutnya proses pembayaran langka yang pertama sistem akan mengeluarkan data pesanan dan harga setelah itu sistem mengeluarkan form pembayaran, pembeli mengirimkan bukti pembayaran, data pembayaran akan tersimpan di data pembayaran, dari sistem akan mengeluarkan validasi pembayaran ke pembeli, setelah itu langsung mengirimkan barang ke pelanggan, data barang yang sudah terkirim akan tersimpan di data pengiriman untuk bukti . Terakhir setelah semua transaksi di lakukan adalah pembuatan laporan, di sini sistem akan mengambil semua data untuk di jadikan sebuah laporan yang akan di krim ke admin, di sini sistem secara otomatis mngambil data akun pelanggan , jumlah data pesanan pelanggan, data pembayaran, dan data pengiriman.

Berikut adalah analisa alur data dan proses yang ada pada sistem penjualan perlengkapan caci:

\subsubsection{Diagram Berjenjang}

Diagram adalah suatu gambar yang bertujuan untuk memperlihatkan bahkan menerangkan suatu data yang akan kita sajikan. Definisi lain diagaram adalah sebagai lambang-lambang tertentu yang mana sering dipakai untuk menjelaskan suatu sarana, prosedur, maupun kegiatan-kegiatan yang telah biasa dilaksanakan dalam suatu sistem. Berikut adalah diagram berjenjang proses penjualan perlengkapan Caci di gambar sebagai berikut:

\subsubsection{Desain database sistem penjualan perlengkapan caci}

Basis data adalah kumpulan informasi yang disusun berdasarkan, Cara tertentu yang merupakan satu kesatuan yang utuh. Dengan sistem tersebut data yang terhimpun dalam suatu database dapat mengasilkan informasi yang berguna.

Pada bagian ini di jelaskan mengenai conceptual data model (CDM) dan physical data model(PDM)Untuk merancang database sistem informasi penjualan perlengkapan Caci

\subsubsection{Physcal Data Model (PDM)}

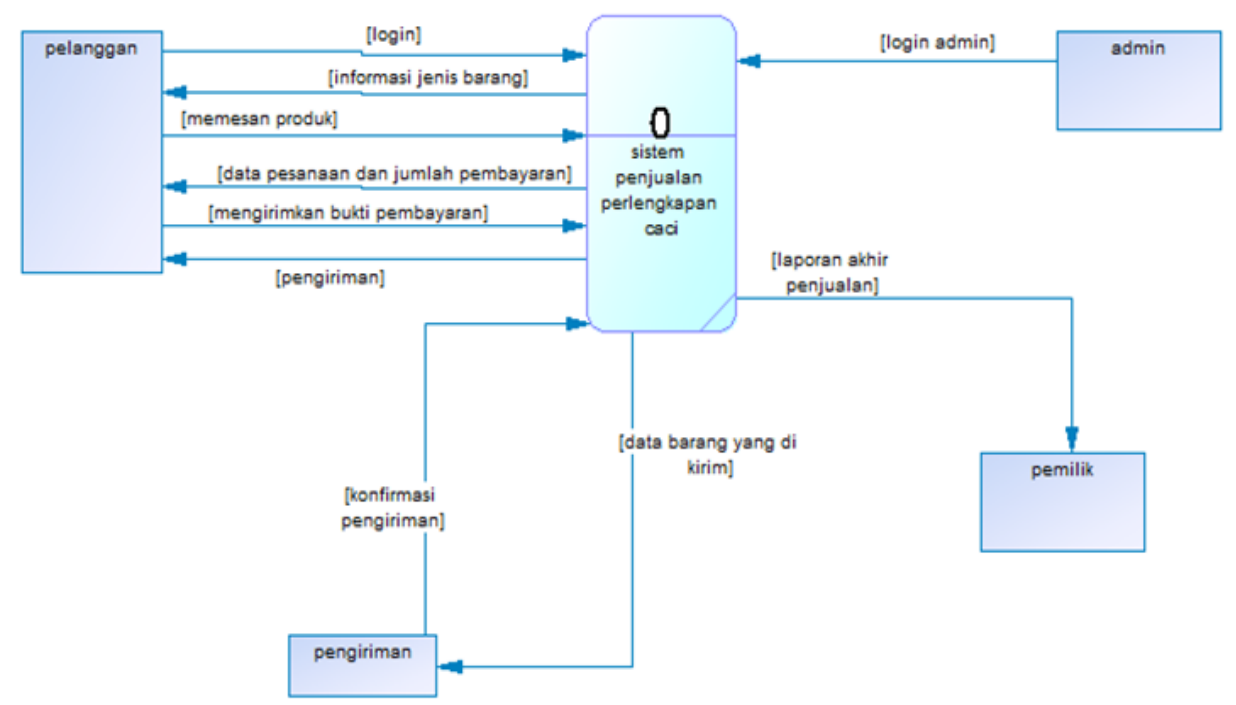

Gambar 3 DFD level kontex sistem penjualan perlengkapan caci 
pISSN: 2442-3386 elSSN: 2442-4293

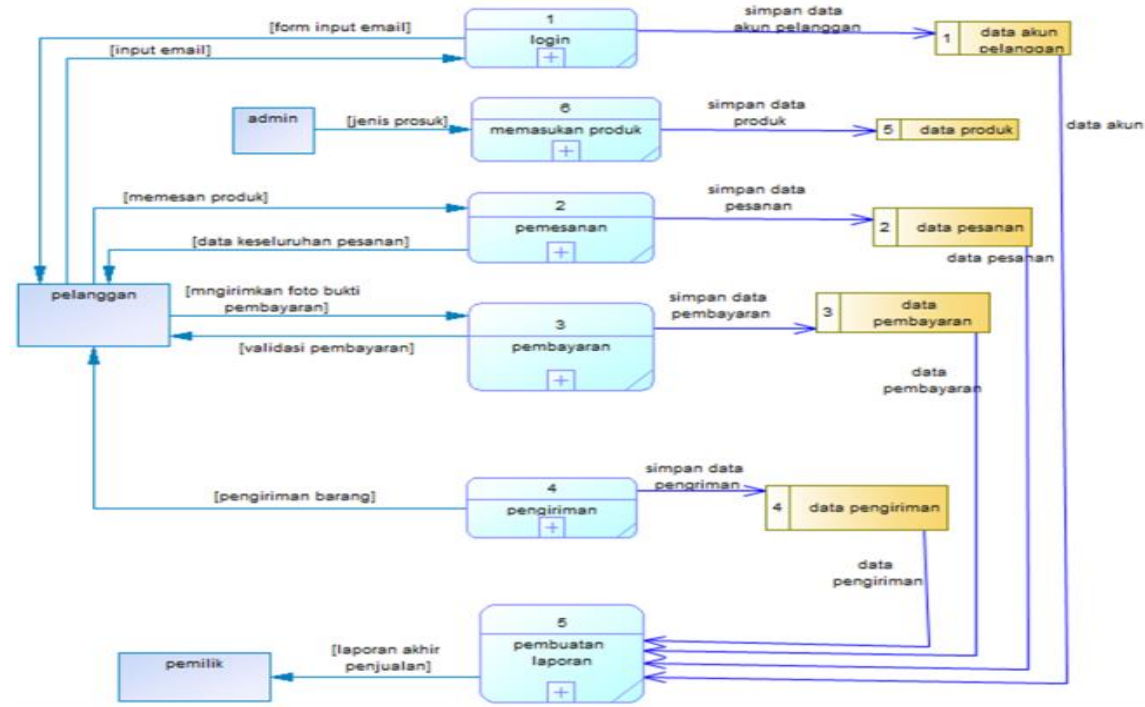

Gambar 4 DFD level 1 sistem penjualan perlengkapan caci

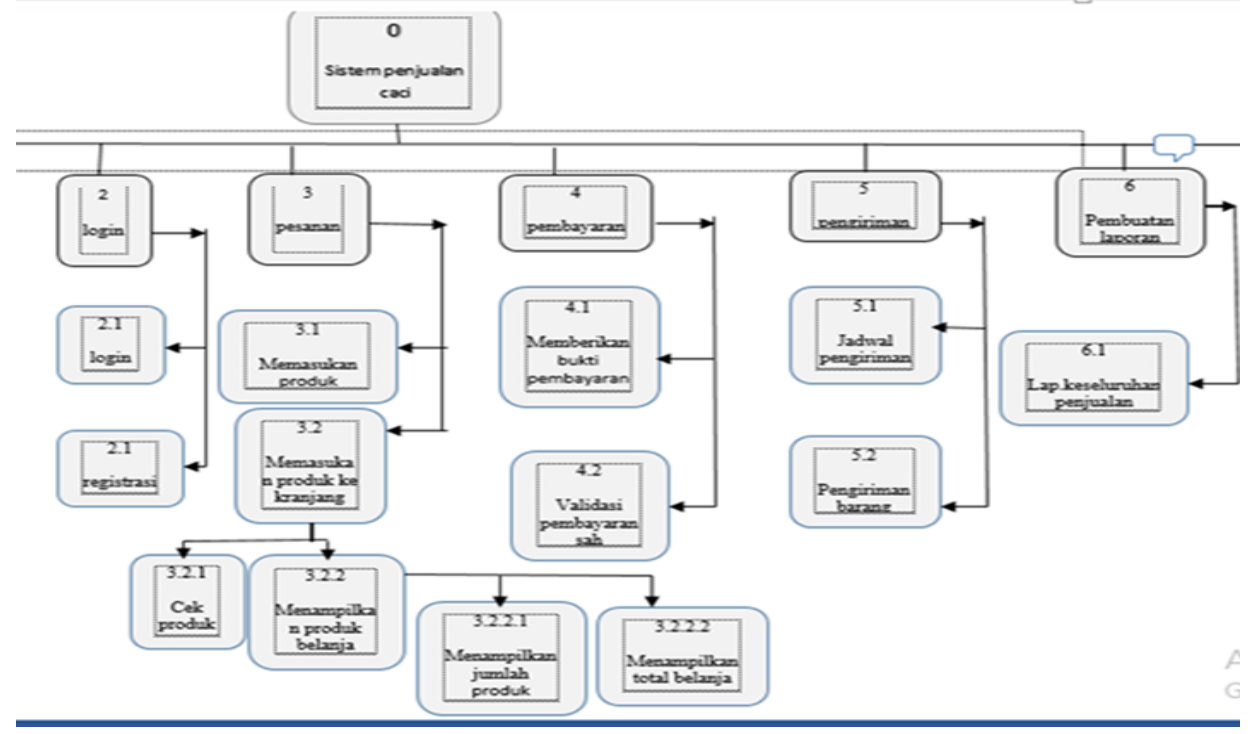

Gambar 5 diagram berjenjang

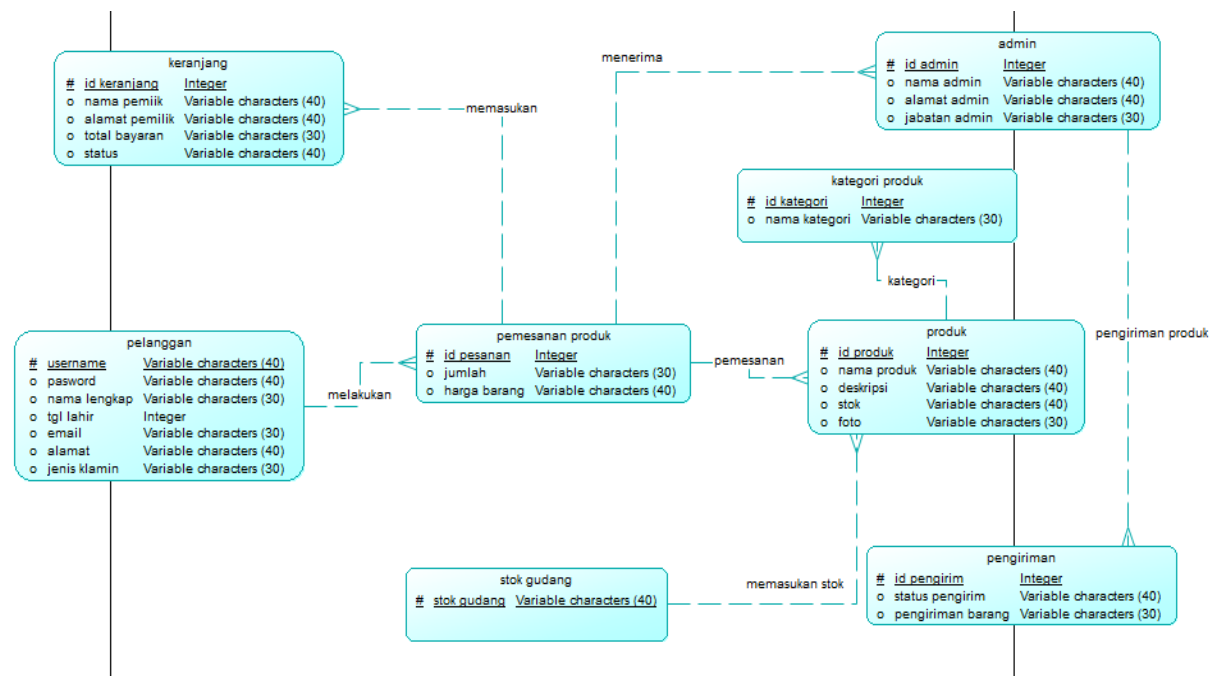

Gambar 6 conceptual data modeling (CDM) 


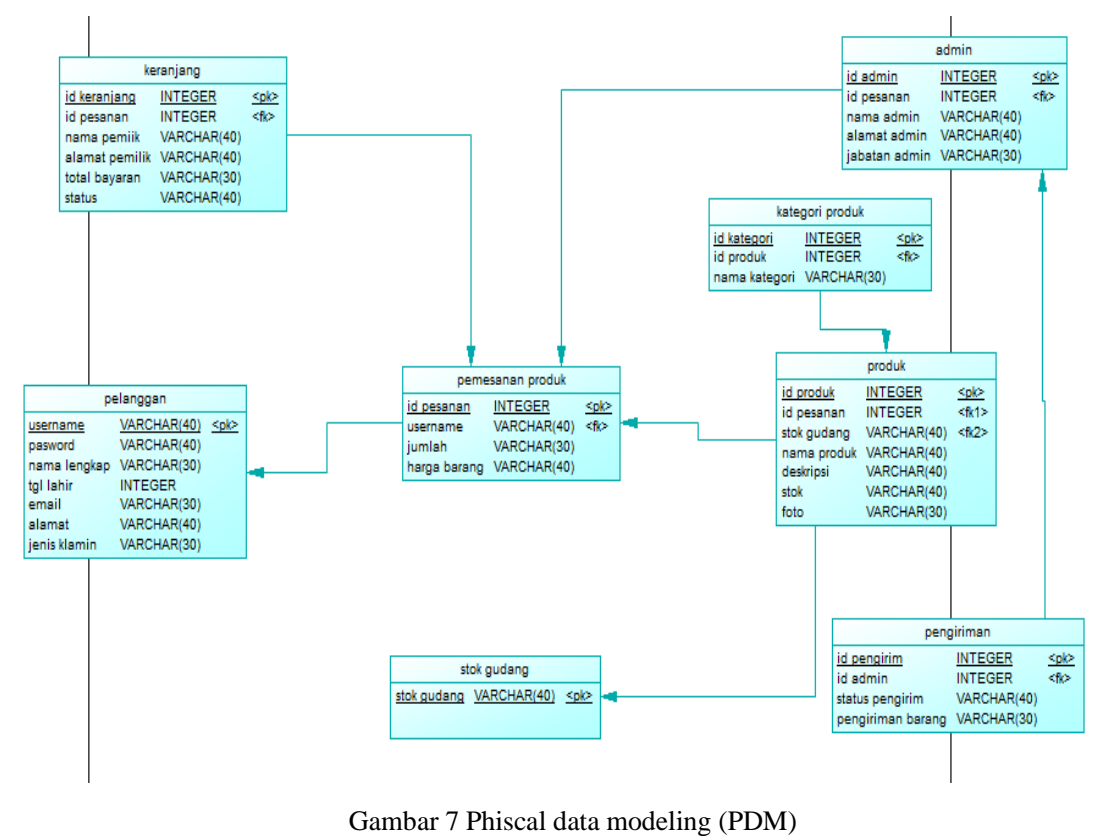

\subsubsection{Flowchart proses sistem penjualan perlengkapan Caci}

Berisi rancangan proses sistem informasi penjualan perlengkapan Caci.meliputi proses registrasi akun, proses pemesanan, proses pembayaran dan proses pengiriman.

Berikut adalah proses flowchart pada sistem penjualan perlengkapan Caci.

\subsubsection{Flowchart registrasi akun}

Di sini sistem akan menampilkan form registrasi akun, pembeli login jika pembeli sudah punya akun maka dia langsung login dengan masuk email dan password, jika pembeli belum punya akun maka dia akan melakukan registrasi, maka dri sistem akan menampilkan form registrasi dan pembeli akan melakukan registrasi, setelah semua sudah registrasi akun maka data akun akan di simpan di data akun, selesai.

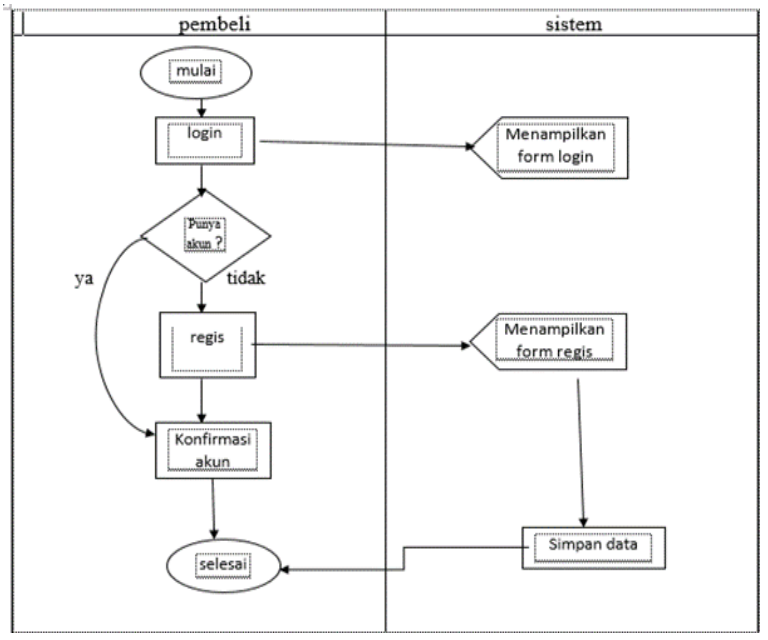

Gambar 8 flowchart registrasi akun

\subsubsection{Flowchart pemesanan}

Di sini pembeli akan memilih produk, dari sistem akan menampilkan data pesanan dan list keseluruhan pesanan, pembeli akan melakukan konfirmasi pemesanan barang, pembeli juga melakukan konfirmasi simpan data pesanan, selesai.

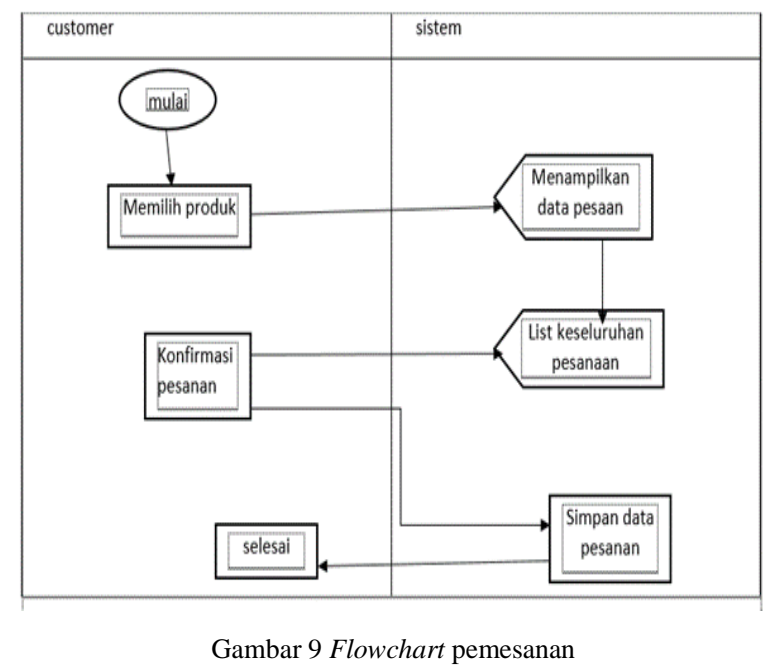

\subsubsection{Flowchart pembayaran}

Di sini pembeli melakukan transaksi pembayaran, pertama sistem menampilkan form pembayaran pembeli melakukan transaksi, setelah melakukan transaksi sistem akan menyimpan data pembayaran dan akan keluar notifikasi pembayaran,setelah itu admin memvalidasi transaksi pembayaran pembeli,sistem akan menyimpan validasi pembayaran pembeli dan sistem menampilkan informasi pembayaran, pembeli melakukan konfirmasi pembayaran, selesai. 


\section{Vol 7 No 1 Januari 2021, (hal) 109-112 INFORMATION IECHNOLOGY JOURNAL}

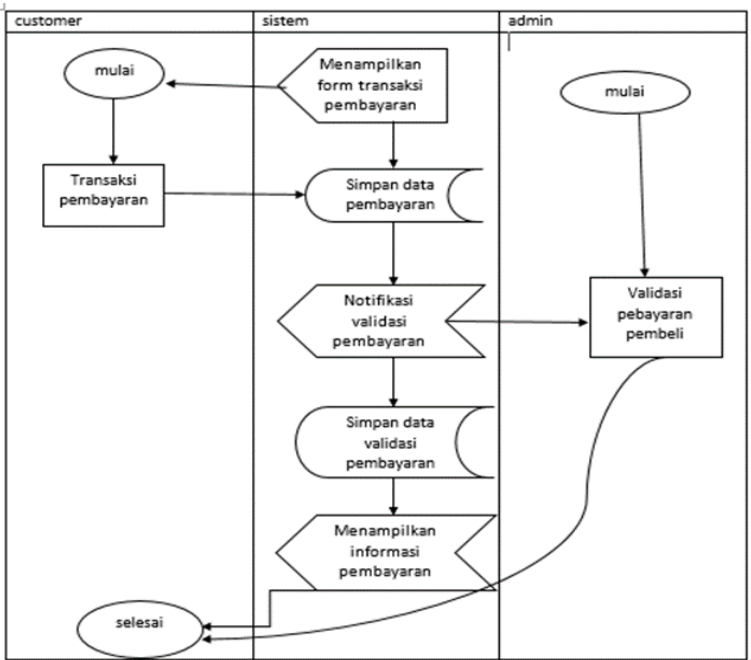

Gambar 10 Flowchart pembayaran

\subsubsection{Flowchart Pengiriman}

Pada proses pengiriman produk tahap awal sistem menmpilkan form tanggal pengiriman, setelah sistem memasukan form pengiriman admin memasukan tanggal pengiriman barang, sistem akan menyimpan data tanggal pengiriman dan menampilkan tanggal pengiriman kemudian pembeli akan konfirmasi tangal pengiriman, selesai.

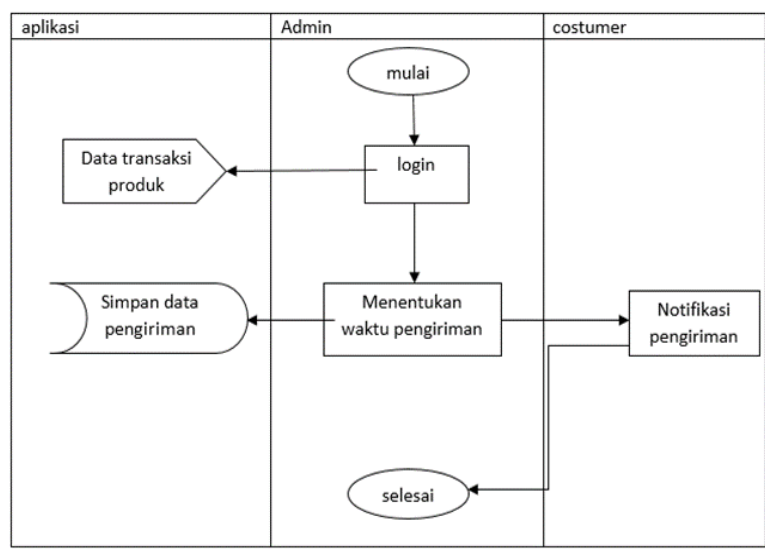

Gambar 11 Flowcart pengiriman

\subsection{Implementasi Sistem}

Dalam tahapan implementasi sistem dilakukan melalui pembuatan sistem yang terstruktur sesuai dengan analisa perancangan sistem dan pengumpulan data yang telah dilakukan. Dan pada tahapan ini juga menggunakan tools dalam pembuatan sistem informasi penjualan perlengkapan Caci berbasis web, bahasa pemrograman yang digunakan dalam merancang sistem yaitu PHP, MYSQL, dan software Xampp yang mendukung dalam pengujian sistem yang akan ditampilkan pada halaman browser apakah informasi yang sudah sesuai dengan kebutahan user atau masih ada bagian - bagian yang perlu dievaluasi.

\subsection{Pengujian Sistem}

Pada tahapan pengujian sistem ini akan diuji apakah sistem informasi penjualan perlengkapan Caci sudah sesuai dengan kebutuhan penguna atau masih ada yang belum kebutuhan informasi yang belum sesuai maka akan dilakukan pengecekan dan perbaikan sistem dengan melihat kembali analisa kebutuhan sistem yang belum terpenuhi dalam pengujian sistem tersebut.

\section{Dokumentasi}

Berisi laporan Tugas Akhir dari langkah awal pembuatan sampai proses akhir.

\section{IMPLEMENTASI DAN UJI COBA SISTEM}

Berdasarkan Tujuan pembuatan sistem yang sudah di bahas pada bab sebelumnya maka pada bab ini akan menjelaskan tentang implementasi dan pengujian sistem sesuai tujuan penelitian yang di bahas pada bab sebelumnya. Berikut uji coba sistem di antaranya:

\subsection{Proses menampilkan semua jenis produk yang di jual}

Pada proses ini sistem akan menampilkan semua produk yang di jual, di sini konsumen bisa melihat keseluruhan produk yang jual di toko ratu.
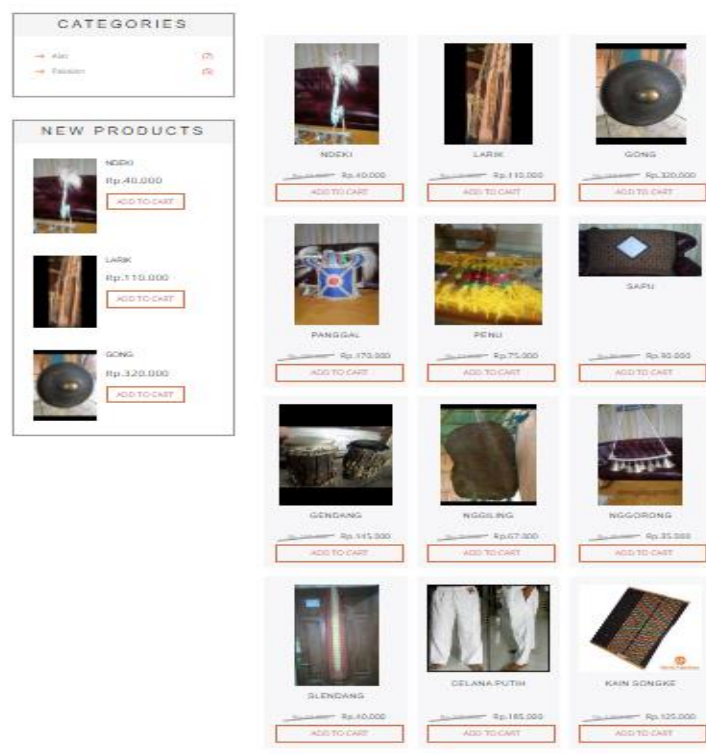

Gambar 12 Halaman penjualan produk

\subsection{Proses menampilkan produk kategori (alat)}

Pada proses ini sistem akan menampilkan produk kategori alat. Di sini konsumen bisa menekan di kategori alat maka sistem akan menampilkan keseluruhan produk kategori alat. Dan konsumen bisa melihat keseluruhan tampilan produk kategori alat. 


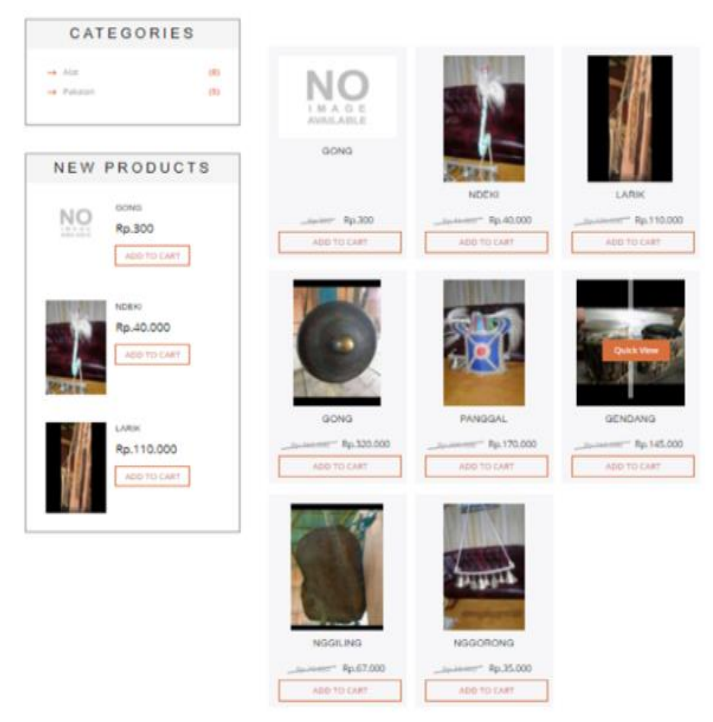

Gambar 13 Halaman Kategori Alat

\subsection{Proses menampilkan produk kategori} (pakayan)

Pada proses ini sistem akan menampilkan produk kategori pakayan, konsumen bisa menekan pada kategori produk pakayan, maka sistem akan menampilkan seluruh produk kategori pakayan, konsumen bisa melihat keseluruhan produk kategori pakayan.

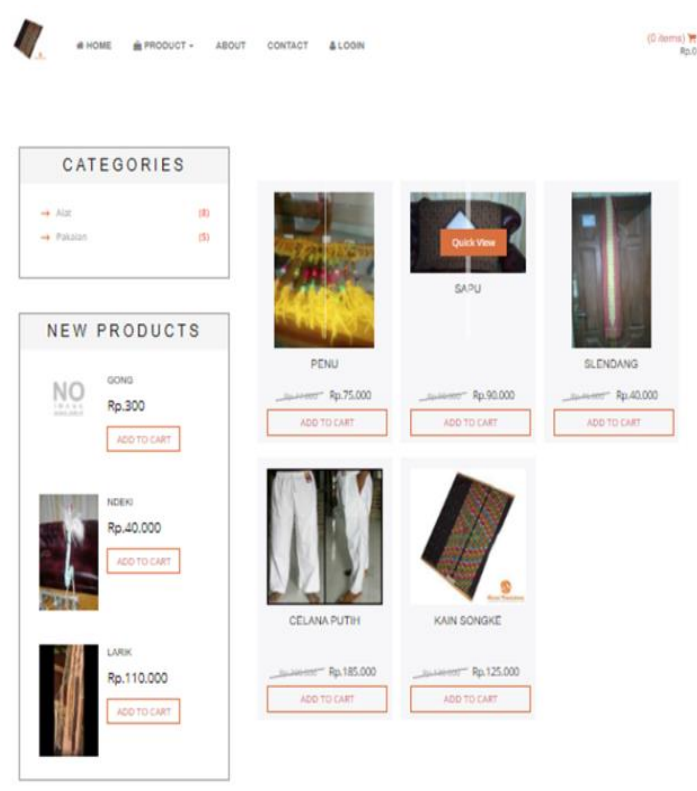

Gambar 14 Halaman Kategori Pakayan

\subsection{Proses menampilkan detail produk}

Pada proses ini sistem akan menampilkan detail produk yang di jual, sistem akan menampilkan detail nama, harga. Konsumen bisa melihat jenis barang yang di jual, detail harga barang.

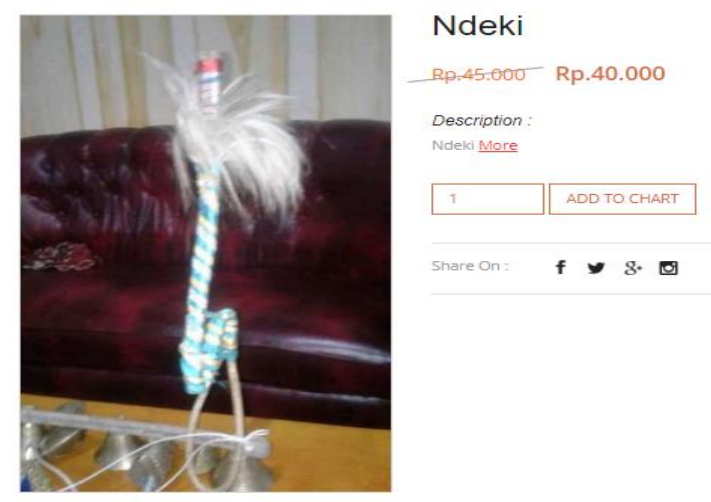

Gambar 15 Halaman Detail Produk

\subsection{Proses menampilkan keranjang belanja}

Pada proses ini konsumen akan memasukan barang yang di beli ke keranjang belanja, dari kerjanjang belanja akan menampilkan secara detail barang yang di beli, detail nama barang, detail harga barang dan detail diskon harga barang,setelah itu konsumen akan menekan tombol keranjang belanja dan di suru transaksi selanjutnya.

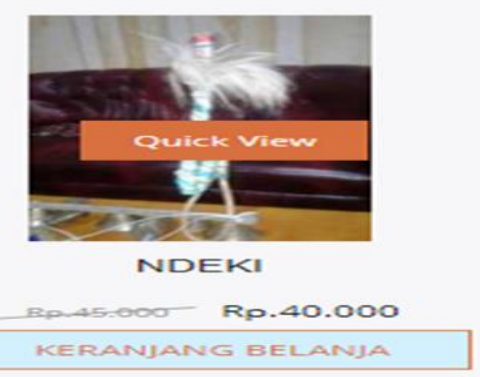

Gambar 16 Halaman Menampilkan Keranjang Belanja

\subsection{Proses menampilkan halaman register}

Pada proses ini konsumen melakukan registrasi, setelah memasukan barang ke keranjang belanja maka konsumen akan melakukan registrasi, konsumen akan melakukan pengisian data diri.Setelah memasukan semua data diri terus menekan register Data konsumen akan tersimpan dan konsumen bisa melakukan transaksi selanjutnya.

\section{Register Here}

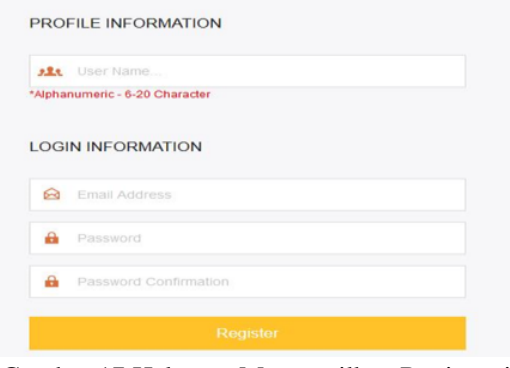

Gambar 17 Halaman Menampilkan Registrasi 


\subsection{Proses menampilkan detail barang belanja}

Pada proses ini sistem akan menampilkan secara detail barang belanja yang di pesan konsumen, detail barang, jumlah barang yang di pesan, total harga barang.

YOUR SHOPPNG CART CONTANS: 1 PRODUCTS

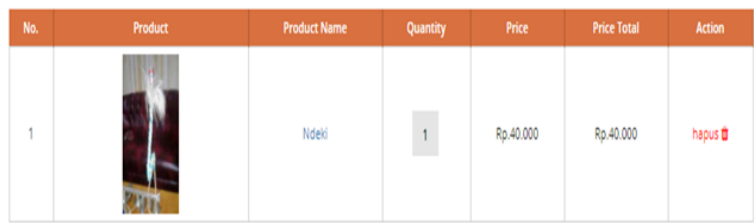

Gambar 18 Halaman Menampilkan Detail Belanja

\subsection{Proses menampilkan pengiriman produk}

Pada proses ini sistem akan menampilkan harga barang yang di pesan stelah itu sistem akan menampilkan form pengiriman, konsumen di suruh untuk mengisi data diri lengkap, alamat kota, provinsi, kode pos, nomor telephone, konsumen juga memilih tipe pengiriman.stelah semua di isi maka dari sistem akan keluar total pembaryaran barang dan ongkos krirm barang.
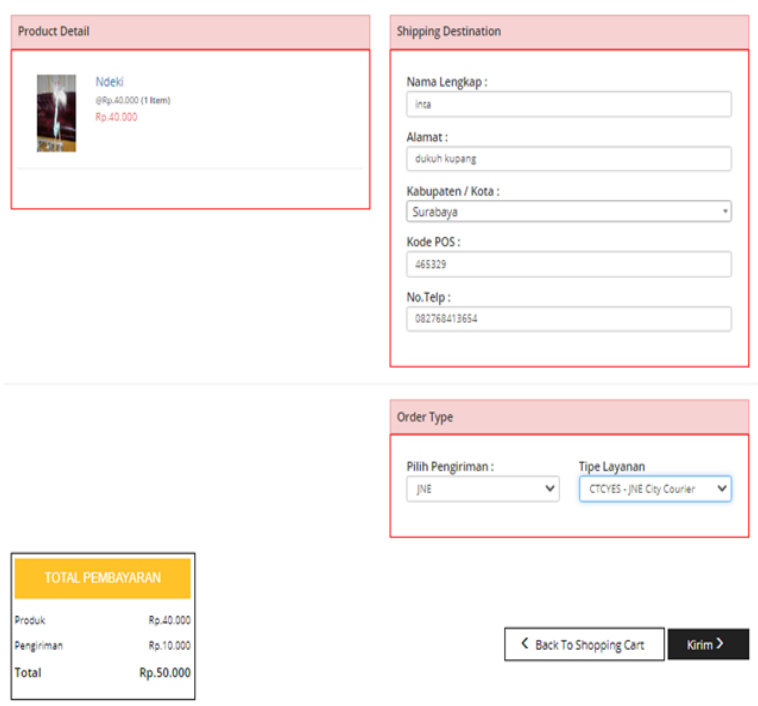

Gambar 19 Halaman Menampilkan Pengiriman Produk

\section{PENUTUP}

\subsection{Kesimpulan}

Dari uraian dan pembahasan yang dilakukan pada bab sebelumnya dapat dibuat kesimpulan sebagai berikut:

1. Aplikasi Caci fleksibel Dengan adanya menu menu yang ada pada sistem penjualan perlengkapan caci seperti menu produk, menu kategori produk, harga produk memudahkan pelanggan untuk mengetahui informasi Tentang Caci.
2. Aplikasi ini di buat untuk melakukan transaksi pembelian dan pemesanan barang yang di lakukan oleh pelanggan secara online.

\subsection{Saran}

Dari hasil penelitian masi banyak kekurangan, penulis menyadari bahwa masi ada peroses pengembangan lanjutan untuk menyempurnakan aplikasi penjualan perlengkapan Caci.

1. Sistem yang dibuat diharapkan diterapkan sebaiknya harus benar-benar dikaji dan dipelajari secara mendalam, sehingga dapat mempermudah dalam penggunaan sistem baru.

2. Dalam tampilan website dapat lebih diperbaiki agar bisa menarik para konsumen untuk melakukan pembelian pada sistem penjualan perlenkapan caci.

Dalam penampilan website lebih di perbaiki agar konsumen dapat menarik daya beli pelanggan.

\section{DAFTAR PUSTAKA}

[1] Pengertian-sistem-menurut,"Romney dan Steinbart (2015:3).

[2] Anastasia Diana \& Lilis Setiawati (2011:3).

[3] GordonB.Davis,"pengertianinformasi",sarjanaku .com,1991[online

Avaliabel:http://www.sarjanaku.com/2012s/11/. A.kadir."pengertian system informasi,"2014:61.

[4] Ikamarsta Pentaskan Tarian Perang (Caci) Manggarai di Jogja". Kompasiana. 2011-10-16. Diakses tanggal 12-03-2011.Caci, Budaya Manggarai Yang Belum Hilang". Nida Fs. Kompasiana. Diakses tanggal12-03 2011.

[5] Siti Rohaya, "internet," pengertian, sejarah, Fasilitas dan Koneksi, 2014.

[6] Gregorius, “pengertian Website,"2000 : 30.

[7] MADCOMS (2005), Membuat Aplikasi DataBase Karyawan Online Berbasis Web dengan PHP dan MySQL, Penerbit ANDI Yogyakarta.

[8] Kai 'oswalad' seidler and kay Vogelgesang, "pengertian Xampp," Dosen pendidikan,2014. [Online]. Avaiable

[9] Kendall, "pengertian data flow diagram," aplikasi penerimaan mahasiswa baru,2003

[10] Jogiyanto, "symbol dan tahapan data flow diagram," aplikasi penerimaan mahasiswa baru, 2015.

[11] B, Indra Yatini. (2010). Flowchart, Algoritma dan Pemrogaman Menggunakan Bahasa $\mathrm{C}++$ Builder. Yogyakarta : Penerbit Graha Ilmu.

[12] K.kendall \&, System Develoment Life Cycle,Camdem,New jersey:School Of Business - Camdem,2016. 
Melek IT

Information Technology Journal. Vol 7 No 1 Januari 2021, 112 - 112 